\title{
Effect of asiatic and ursolic acids on morphology, hydrophobicity, and adhesion of UPECs to uroepithelial cells
}

\author{
Wojnicz Dorota • Kicia Marta • Tichaczek-Goska Dorota
}

Received: 28 March 2012 / Accepted: 23 October 2012 /Published online: 7 November 2012

(C) The Author(s) 2012. This article is published with open access at Springerlink.com

\begin{abstract}
Adhesion of bacteria to epithelial tissue is an essential step in the progression of the urinary tract infections. Reduction of virulence factors responsible for microbial attachment may help to decrease or inhibit colonization of the host organism by pathogens. In the age of increasing bacterial antibiotic resistance, more and more attention is being paid to the use of plants and/or their bioactive components in the prevention and treatment of human infections. Asiatic acid (AA) and ursolic acid (UA), two plant secondary metabolites, were used as potential antibacterial agents. The current study aimed to determine the possible impact of AA and UA on morphology, hydrophobicity, and adhesion of clinical uropathogenic Escherichia coli strains (UPEC) to the uroepithelial cells. Our work describes for the first time the effects exerted by AA and UA on virulence factors of UPECs. The impact of both acids on the cell surface hydrophobicity of the investigated strains was very weak. The results clearly show the influence of AA and UA on the presence of $\mathrm{P}$ fimbriae and curli fibers, morphology of the UPECs cells and their adhesion to epithelium; however, some differences between activities of AA and UA were found.
\end{abstract}

\section{Introduction}

In most infectious diseases, the adherence of pathogenic organisms to the host tissues is an essential step of invasion leading to colonization (Pizarro-Cerda and

W. Dorota $(\bowtie) \cdot$ K. Marta $\cdot$ T.-G. Dorota

Department of Biology and Medical Parasitology,

Wroclaw Medical University,

Mikulicza-Radeckiego 9,

50-367 Wroclaw, Poland

e-mail: dorota.wojnicz@am.wroc.pl
Cossart 2006). Both specific (ligand-receptor like) and nonspecific (physicochemical) interactions may play an important role in the attachment ability of bacteria to the epithelial cells. Various outer membrane components such as fimbrial and afimbrial adhesions, flagella, proteins, and lipopolysaccharides are responsible for specific interactions between bacteria and the host cells. Bacterial adhesion is also governed by van der Waals forces, hydrogen bonding, electrostatic, and hydrophobic interactions. The role of adherence in the ability of uropathogenic Escherichia coli strains (UPECs) to induce urinary tract infections (UTIs) has been extensively studied (Mulvey 2002). Both P and type 1 fimbriae play a particular role in the adhesiveness of UPECs (Melican et al. 2011). Bacterial binding is also mediated by the hydrophobic interactions between uropathogenic rods and uroepithelial cell surfaces. It is known that adherence of bacteria to the epithelium is correlated with increasing cell surface hydrophobicity of the microorganism (Saralaya et al. 2004; Wojnicz and Jankowski 2007). Changes of the nature of bacterial cell surface could alter their adhesive capacity and thus reduce the spread of the infection in the human body.

Currently, many reports describe plants and their secondary metabolites as a promising source of potentially therapeutic agents. One of the most bioactive plant components are pentacyclic triterpenes (Chung et al. 2011). Their antimicrobial, anti-inflammatory, and antitumor activities have been reported (Cho et al. 2006; Fontanay et al. 2008; Ikeda et al. 2008; Filocamo et al. 2011). To our knowledge, triterpenes have not previously been studied for their bacterial anti-adhesive properties. Therefore, the purpose of our study was to determine the effect of AA and UA on the P fimbriae and curli fibers expression, cell surface hydrophobicity of uropathogenic $E$. coli strains and their ability to adhere to the human uroepithelium. Furthermore, the impact 
of both pentacyclic triterpenes on the cells morphology was assessed.

\section{Materials and methods}

\section{Bacterial strains}

Twenty uropathogenic E. coli strains were isolated from the urine specimens of patients with pyelonephritis, hospitalized in the Academic Clinical Centre of the Wrocław Medical University. E. coli identification was done by biochemical methods using the API-20E test kit (BioMérieux, Warsaw, Poland). The strains were maintained on Mueller-Hinton agar slopes (Oxoid) at $4{ }^{\circ} \mathrm{C}$.

Phylogenetic classification

Phylogenetic group was determined using primers specific for two genes (chuA and yjaA) and DNA fragment (TspE4.C2) according to the multiplex PCR method of Clermont at al. (2000), however the yjaA sequence was amplified separately. For this, the genomic DNA of each strain was isolated using GeneMATRIX Bacterial \&Yeast Genomic DNA Purification Kit (EURx, Poland). The amplification products were separated by electrophoresis in a $2 \%$ agarose gel. Gel images were visualized and analyzed using the Quantity One system (Bio-Rad). The strains were assigned to phylogenetic group $\mathrm{B} 2\left(\operatorname{chu} A^{+}, y j a A^{+}\right)$or $\mathrm{D}$ $\left(\right.$ chuA,$\left.+ y j a A^{-}\right)$or B1 (chuA-, TSPE4.C2+) or A (chuA-, TSPE4.C2-).

\section{Antimicrobial agents}

AA (purity, $\geq 97 \%$ ) and UA (purity, $\geq 90 \%$ ) were purchased from Sigma-Aldrich (Poznań, Poland). Stock solutions at a concentration of $10 \mathrm{mg} / \mathrm{mL}$ were prepared by dissolving acids in $96 \%$ ethanol at $70{ }^{\circ} \mathrm{C}$ and stored at $-20{ }^{\circ} \mathrm{C}$. For all experiments, final concentrations of triterpenes were prepared by diluting the stock with Mueller-Hinton broth (MHB).

\section{Antimicrobial testing}

The minimal inhibitory concentrations (MICs) of AA and UA were determined by the broth microdilution method recommended by the Clinical Laboratory Standard Institute (CLSI 2008). Briefly, the stock solutions $(10 \mathrm{mg} / \mathrm{mL})$ of triterpenes were dissolved in MHB to give the concentrations of $4,096 \mu \mathrm{g} / \mathrm{mL}$ and then diluted twofold to achieve the concentrations from 4 to $1,024 \mu \mathrm{g} / \mathrm{mL}$. Then, $200 \mu \mathrm{L}$ of each concentration was added in well (96-well microplate) and inoculated with the tested strains, yielding a bacterial density of $5 \times 10^{6} \mathrm{CFU} / \mathrm{mL}$. After $24 \mathrm{~h}$ incubation at $37^{\circ} \mathrm{C}$, the MIC was defined as the lowest concentration that inhibited bacterial growth. Each assay was repeated three times.

Effect of AA and UA on P fimbriae expression

UPEC strains were incubated with $\mathrm{AA}$ and UA at concentrations of $10,20,30,40$, and $50 \mu \mathrm{g} / \mathrm{mL}$ for $24 \mathrm{~h}$ at $37^{\circ} \mathrm{C}$ and next were washed three times in phosphate-buffered saline (PBS). Equal volumes of bacterial suspensions $(0.5$ McFarland) and $3 \%$ solution of human erythrocytes with or without D-mannose were mixed to determine the ability of the tested strains to haemagglutination (Evans et al. 1980).

Effect of AA and UA on curli fibers expression

E. coli strains were incubated with AA and UA (10-50 $\mu \mathrm{g} /$ $\mathrm{mL}$ ) for $24 \mathrm{~h}$ at $37{ }^{\circ} \mathrm{C}$. After incubation, bacteria were washed three times and next $10 \mu \mathrm{l}$ of bacterial suspensions were inoculated onto YESCA agar plates containing congo red. Curli-producing E. coli bound to Congo red dye and formed red colonies, whereas curli-negative bacteria formed white colonies (Hammar et al. 1995).

Effect of AA and UA on hydrophobicity of bacterial cells

UPEC strains were incubated with AA and UA at concentrations of $10,20,30,40$, and $50 \mu \mathrm{g} / \mathrm{mL}$ for $24 \mathrm{~h}$ at $37^{\circ} \mathrm{C}$. Following the incubation, bacterial cells were washed three times in PBS. After last centrifugation, the bacterial suspensions were diluted to obtain final optical density (measured at $470 \mathrm{~nm}$ ) of 1.0. Untreated cells were assessed as a control. The salt aggregation test (SAT) of ammonium sulfate was used (Lindahl et al. 1981). The control and treated suspensions $(20 \mu \mathrm{L})$ were mixed with a series of dilutions of ammonium sulfate $(20 \mu \mathrm{L})$ ranging from 0 to $3.2 \mathrm{~mol} / \mathrm{L}$. The lowest concentration of ammonium sulfate at which bacteria aggregated was determined. Based on the SAT values, the strains were classified as: $0.1-0.2 \mathrm{~mol} / \mathrm{L}$, very strong hydrophobic; $0.4-1.0 \mathrm{~mol} / \mathrm{L}$, strong hydrophobic; $1.2-1.6 \mathrm{~mol} / \mathrm{L}$, hydrophobic; $\geq 1.8 \mathrm{~mol} / \mathrm{L}$, hydrophilic.

Effect of AA and UA on adhesion to epithelial cells

The cell adhesion assay was performed essentially as described previously (Wojnicz et al. 2012). Human uroepithelial cells from fresh urine of nonbacteriuric females were resuspended in PBS to give $10^{5}$ cells per milliliter (Bürker chamber count). Bacteria were grown in MHB in the presence of $10-50 \mu \mathrm{g} / \mathrm{mL}$ AA and UA, harvested by centrifugation $(4,000 \mathrm{rpm}$ for $20 \mathrm{~min})$, resuspended in PBS and adjusted to a concentration of $1.5 \times 10^{8} \mathrm{CFU} / \mathrm{mL}$. Equal volumes of epithelial cells and pentacyclic triterpene-treated 
bacterial suspensions were incubated for $1 \mathrm{~h}$ at $37{ }^{\circ} \mathrm{C}$ with shaking. Unattached bacteria were removed from the suspension by centrifugation (200 rpm for $20 \mathrm{~min}$ ) and washing three times in PBS. The final pellets were air dried on glass slides and May-Grünwald stained. The attached bacteria on 40 separate cells were counted by direct light microscopy (Nikon Eclipse 400) and adherence was determined as the mean number of bacteria attached per cell. Control values were determined using epithelial cells mixed with bacteria without AA and UA (Jahanshahi et al. 2010).

Effect of AA and UA on bacterial cell morphology

The strains were incubated at $37^{\circ} \mathrm{C}$ for $24 \mathrm{~h}$ with AA and UA at concentrations of 50,150 , and $250 \mu \mathrm{g} / \mathrm{mL}$. The bacterial samples were then washed three times in PBS. The final pellets were air dried on glass slides and Gram-stained and observed in Nikon Eclipse 400 microscope. The shape of bacterial cells and the length of the filaments and their proportions in the total number of microorganisms per 100 randomly observed bacteria were recorded. The microorganisms with length of 5-15 $\mu \mathrm{m}$ were classified as short filaments, those with $>15 \mu \mathrm{m}$ as long filaments. Experiments were done separately three times.

\section{Statistical analysis}

All values are given as mean $\pm \mathrm{SD}$. The differences in adhesion and morphology between rods exposed to AA and UA and unexposed were analyzed by a $t$ test for independent samples. All tests were analyzed at the significance level $P<0.05$ using Statistica 7.1.

\section{Results}

Molecular characterization of bacterial strain

PCR assays revealed that the $20 \mathrm{E}$. coli isolates fell into two phylogenetic groups B2 $(n=16,80 \%)$ and D $(n=4,20 \%)$.

Antibacterial activity

The MIC values of AA and UA against the 20 isolates of $E$. coli were high and distributed in a range from $512 \mu \mathrm{g} / \mathrm{mL}$ to $>1,024 \mu \mathrm{g} / \mathrm{mL}$.

Effect of AA and UA on P fimbriae expression

All tested $E$. coli strains expressed P fimbriae. All concentrations of both acids caused the loss of the ability to agglutinate human erythrocytes. Results are shown in Table 1.
Effect of AA and UA on curli fibers expression

All examined E. coli rods were curli-producing strains. As shown in Table 1 only the highest concentrations of AA and UA (40 and $50 \mu \mathrm{g} / \mathrm{mL}$ ) affected the synthesis of curli fibers.

Effect of AA and UA on hydrophobicity of bacterial cells

Of the 20 studied $E$. coli strains, four possessed very strong hydrophobic surface - they aggregated at $0.1-0.2 \mathrm{~mol} / \mathrm{L}$ of ammonium sulfate. The cell surfaces of 11 strains were strongly hydrophobic exhibiting aggregation at $0.4-$ $1.0 \mathrm{~mol} / \mathrm{L}$ of ammonium sulfate. The rest of the strains displayed a hydrophilic nature. In the next stage of our study, we determined the effect of AA and UA at concentrations of $10,20,30,40$, and $50 \mu \mathrm{g} / \mathrm{mL}$ on the cell surface hydrophobicity of 15 hydrophobic strains. The change of the cells' surface character from very strongly hydrophobic to strongly hydrophobic was observed exclusively at the highest of tested triterpene concentrations $(50 \mu \mathrm{g} / \mathrm{mL})$ in three cases after the treatment with UA and in two cases after exposure to AA.

Effect of AA and UA on adhesion to epithelial cells

The adhesion of 15 UPEC strains with very strongly hydrophobic and strongly hydrophobic cells surface, possessing $\mathrm{P}$ fimbriae and curli fibers, to the uroepithelial cells was determined. The results are shown in Figs. 1 and 2. The mean number of untreated bacterial cells attached to the one uroepithelial cell was $313.0 \pm$ 27.7 (Fig. 2a). The adhesion of all strains was reduced following treatment with both $\mathrm{AA}$ and UA at concentrations of 40 and $50 \mu \mathrm{g} / \mathrm{mL}$. The mean number of bacteria attached to the one epithelial cell was significantly reduced to $69 \%(216.0 \pm 19.2)$ and to $48 \%$ $(152.0 \pm 16.7)$ after the treatment with 40 and $50 \mu \mathrm{g} /$ $\mathrm{mL}$ AA, respectively $(P<0.05$; Fig. $2 \mathrm{~b})$. The effect exerted by UA on the adhesion of UPECs to uroepitheliuim was slightly weaker. The mean number of bacteria attached to the one uroepithelial cell was reduced to $72 \%(225.0 \pm 11.8)$ and $53 \%(166.0 \pm 21.4)$ after incubation in 40 and $50 \mu \mathrm{g} / \mathrm{mL}$ AA, respectively $(P<0.05$; Fig. 2c). These results were also statistically significant $(P<0.05)$. The changes in adhesion of bacteria treated with lower concentrations of acids were statistically insignificant.

Effect of AA and UA on bacterial cell morphology

The control samples of the 20 investigated $E$. coli strains contained rods of normal length $(96.1 \%)$ and short filaments (3.9\%; Table 2). Only the exposure of bacteria to AA 
Table 1 The effect of AA and UA on the presence of P fimbriae and curli fibers in $E$. coli strains $(n=20)$

\begin{tabular}{llll}
\hline & Concentration $(\mu \mathrm{g} / \mathrm{mL})$ & \multicolumn{2}{l}{$\begin{array}{l}\text { Presence of virulence factor } \\
\text { (\% of strains })\end{array}$} \\
\cline { 3 - 4 } & & P fimbriae & Curli fibers \\
\hline \multirow{2}{*}{ AA } & 0 & 100 & 100 \\
& 10 & 80 & 100 \\
& 20 & 65 & 100 \\
& 30 & 65 & 100 \\
& 40 & 60 & 80 \\
& 50 & 60 & 75 \\
& 0 & 100 & 100 \\
& 10 & 80 & 100 \\
& 20 & 65 & 100 \\
& 30 & 65 & 100 \\
& 40 & 65 & 95 \\
& 50 & 65 & 75 \\
\hline
\end{tabular}

and UA at concentration of $250 \mu \mathrm{g} / \mathrm{mL}$ induced morphological changes. The lower concentrations of both triterpenes did not alter bacterial morphology. Significant changes in the shape of bacterial cells were observed after exposure to UA $(P<0.05)$. Microscopic analysis revealed the presence of long $(40.45 \%)$ and short filaments $(10.9 \%)$, ghost cells (2.35\%), and short filaments with mid-cell swellings (1.25\%; Fig. 3). In the UA-containing suspensions, the normal length bacterial cells (45.05 \%) were also observed. AA had a much weaker impact on bacterial morphology. $E$. coli rods exposed to AA formed only short $(6.15 \%)$ and long filaments (2.95\%); neither "swollen" forms nor ghost cells were observed. The normal length bacteria accounted for as much as $90.9 \%$ of the total cell number.

\section{Discussion}

Adhesion of UPECs to the uroepithelium is a crucial step in the pathogenesis and colonization of the urinary tract. The hydrophobic interactions between bacteria and host tissues are important adhesion-promoting factors. Bacterial surface hydrophobicity is correlated with increased pathogenic potential (Dykes et al. 2003). It is well-documented that E. coli strains causing UTIs possess hydrophobic cell surfaces (Najar et al. 2007). We established that 15 out of 20 tested E. coli strains also possessed a hydrophobic character. It may confirm a significant role of this virulence factor among bacterial strains responsible for pyelonephritis. Results of research conducted by Sunman et al. (2001) and Raksha et al. (2003) also showed hydrophobic nature of the cell surface of $E$. coli isolated from patients with UTIs. It is known that the change of the bacterial cell surface from hydrophobic to hydrophilic correlates with the limited colonization of epithelial cells (Wojnicz and Jankowski 2007). The effects of various phyto-extracts on the bacterial cell surface hydrophobicity have been reported in several papers. These plant extracts exhibit modulating activity on the cell surface hydrophobicity of the microorganisms and thus potentially affect their pathogenicity (Barnabas and Nagarajan 1988; Nishino et al. 1987; Rauha et al. 2000; Dykes et al. 2003). For example, the aqueous extract of bearberry has been shown to alter the hydrophobicity of $E$. coli (Turi et al.
Fig. 1 Effect of AA and UA on the adhesion of $E$. coli strain to the uroepithelial cells

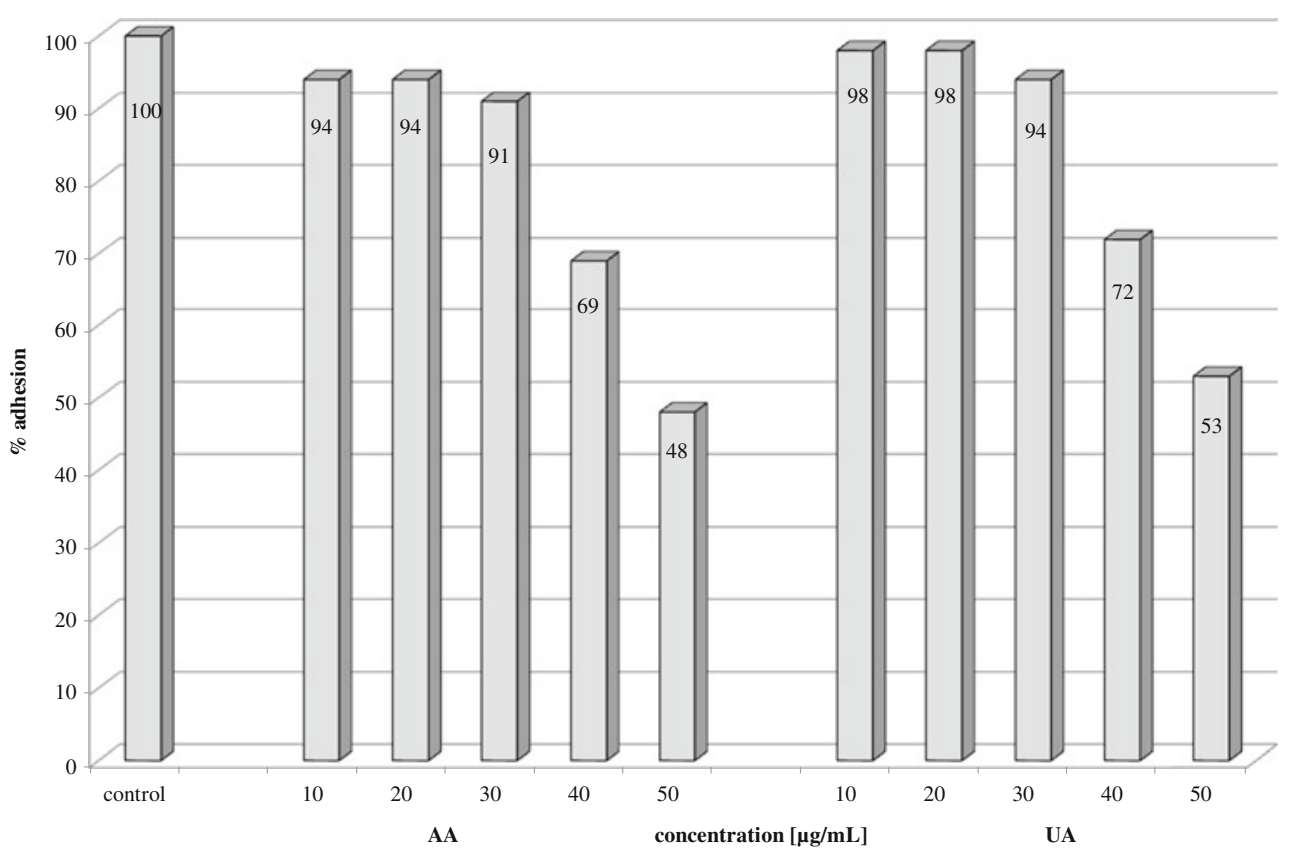



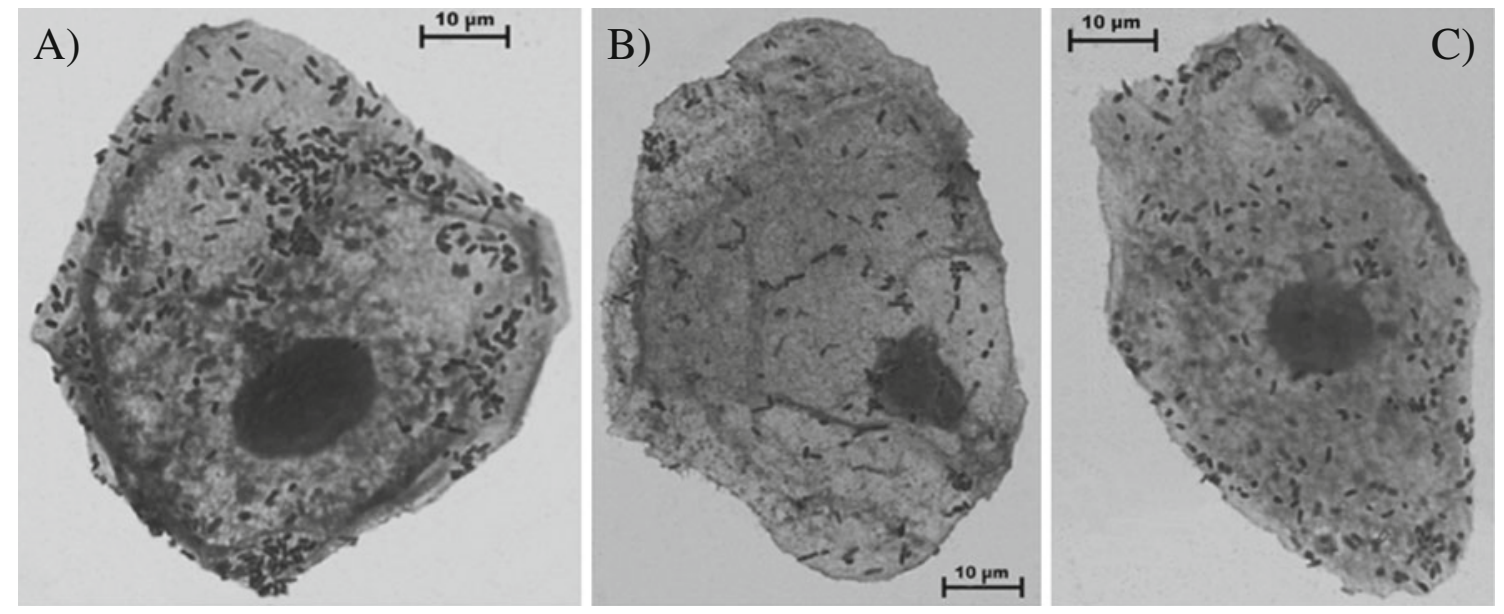

Fig. 2 Adhesion of E. coli strain to the uroepithelial cell unexposed (a), exposed to $50 \mu \mathrm{g} / \mathrm{mL}$ AA (b), and $50 \mu \mathrm{g} / \mathrm{mL}$ UA (c). Magnification, $\times 1,000$

1999) and Helicobacter pylori (Anuuk et al. 1999). In another study, Nostro et al. (2004) found that surface hydrophobicity and adherence of Streptococcus mutans was reduced when bacteria were grown in the presence of the Helichrysum italicum extract.

Due to the absence of reports devoted to the effects of single phytocompounds on the bacterial cell surface hydrophobicity and adherence, we decided to investigate the impact of pentacyclic triterpenes (AA and UA) on these virulence factors. It is known that the biological activities of triterpenes may be related to the effect of these compounds on membranes, especially of the eukaryotic cells (Prades et al. 2011). This phenomenon is related to the structural similarity of pentacyclic triterpenes to cholesterol. These compounds could possibly be incorporated into the biomembranes instead of cholesterol and change their hydrophobic properties. Our study showed that neither AA nor UA have a significant effect on cells surface hydrophobicity. Such limited impact of AA and UA on the tested UPECs may probably be caused by the absence of the cholesterol in bacterial cells. Moreover, pentacyclic triterpenes can form micellar phases that could affect their incorporation into cell membrane and the ability to change the cell surface hydrophobicity (Rafat et al. 2008).

It is worth noting that, despite the weak antihydrophobic activity, both triterpenes significantly reduced the attachment of bacteria to urinary epithelial cells. Adhesion significantly decreased after treatment of bacteria with 40 and $50 \mu \mathrm{g} / \mathrm{mL}$ AA and UA. The mechanism of this inhibitory effect may probably be associated with suppression of the synthesis of the bacterial surface structures such as P fimbriae and curli fibers related to adhesion of rods to the host tissues. We cannot comprehensively discuss our results with respect to other reports because the data from other laboratories mainly describe the changes in the adhesiveness of bacteria treated with plant extracts or fruit juice. Well recognized is the adhesionpreventing activity of Vaccinium macrocarpon against $E$. coli and H. pylori (Johnson-White et al. 2006). Cunningham et al. (2004) and Foo et al. (2000) reported that cranberry proanthocyanidins are responsible for anti-adhesion of $H$. pylori and associated with urinary tract infections $E$. coli rods. Yamanaka et al. (2004) noticed that cranberry juice decreased adsorption of oral streptococci to saliva-coated hydroxyapatite beads. Similarly, extracts of $H$. italicum, Mikania laevigata, Mikania glomerata, Syzygium aromaticum, Piper betle, and Piper guajava showed positive anti-adherence activity to the saliva-coated glass surface against oral streptococci (Nostro et al. 2004; Yatsuda et al. 2005; Rahim and Khan 2006; Razak and Rahim 2003). Only one paper describes the impact of UA on bacterial adherence properties (Moodley et al. 2011). Decreased adhesion to polystyrene surfaces was noticed for E. coli and S. aureus incubated in subinhibitory (subMIC),

Table 2 Morphological changes observed in E. coli strains after incubation with AA and UA

The mean number of cells per 100 randomly observed bacteria

\begin{tabular}{llllll} 
& Normal length $(2-5 \mu \mathrm{m})$ & Short filaments $(5-15 \mu \mathrm{m})$ & Long filaments $(>15 \mu \mathrm{m})$ & "Swollen” filaments & Ghost \\
\hline Control & $96.10( \pm 1.86)$ & $3.90( \pm 1.86)$ & 0 & 0 & 0 \\
AA & $90.90( \pm 2.15)$ & $6.15( \pm 1.63)$ & $2.95( \pm 1.28)$ & 0 & 0 \\
UA & $45.05( \pm 6.00)$ & $10.90( \pm 1.97)$ & $40.45( \pm 4.70)$ & $1.25( \pm 0.64)$ & $2.35( \pm 1.18)$ \\
\hline
\end{tabular}



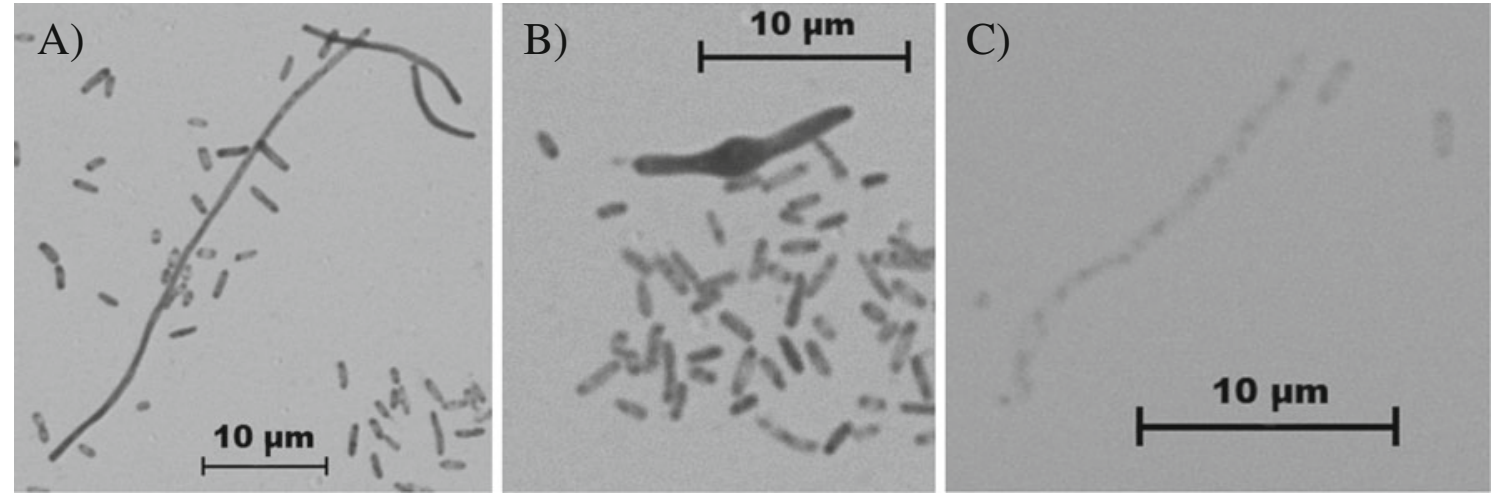

Fig. 3 Morphological changes observed in E. coli strains grown in the presence of UA: a long and short filaments, b filament with mid-cell swellings, $\mathbf{c}$ ghost cell. Magnification, $\times 1,000$

MIC and suprainhibitory (supraMIC) concentrations of UA. For Pseudomonas aeruginosa, decreased adhesion was observed only after exposure to subMIC and MIC of UA, while increased adhesion was observed at supraMIC concentration of this triterpene. In contrast, the adhesion of Staphylococcus saprophyticus to polystyrene surfaces was increased after treatment of bacteria in subMIC but decreased after treatment in MIC and supraMIC concentrations of UA. Moodley et al. (2011) noticed that UA demonstrated the greatest ability to prevent bacterial colonization in comparison to oleanolic acid and methyl oleanolate. It was also interesting that the adhesion of Klebsiella pneumoniae was increased after exposure to all concentrations of UA (Moodley et al. 2011).

In addition to changes in bacterial cell surface hydrophobicity, the alteration of cell morphology can decrease the adhesion of pathogens to host cells. Untreated E. coli appear rod-shaped with the lengths ranging between 2 and $5 \mu \mathrm{m}$. We observed that the exposure of these organisms to the AA and UA resulted in morphological abnormalities. Formation of filaments, ghost cells, and mid-cell swellings forms were recorded. The results were dependent on type of triterpene used. All altered bacterial forms listed above were observed only after the treatment of UPECs with subMIC of UA. Incubation of bacteria with AA led to formation of long filaments, not observed in control samples; however, the percentage of them was very low. Kurek et al. (2010) also investigated the impact of pentacyclic triterpenes UA and oleanolic acid (OA) on the morphology and peptidoglycan synthesis of Listeria monocytogenes. They noticed that the length of bacterial cells was reduced. Szakiel et al. (2008) observed that Bacillus megaterium incubated with $\mathrm{OA}$ also became visibly shorter. In contrast, $E$. coli cells appeared several fold longer after the exposure to this acid. Bacterial filamentation is often observed as a result of DNA damage, inhibition of replication or alteration of FtsZ protein that is key to bacterial cell division (Justice et al. 2006). Morphological alterations observed in E. coli cells after their exposure to AA and UA may indicate that triterpenes can penetrate into the bacterial cells and interact with DNA, proteins involved in the septum formation or affect the replication process.

Based on the differential effects exerted on E. coli by UA and $\mathrm{AA}$, it is possible that they may arise from the differences in the chemical structure of these compounds (Fig. 4). Research conducted by Wen et al. (2005) on the relationship between structure and activity of pentacyclic triterpenes showed the A-ring structure to have a significant impact on biological activity. Despite the structural similarities of the triterpenes in the other rings, the A-ring in AA and UA is very different, with two additional hydroxyl groups in AA which could possibly affect bacterial length and shape.

In conclusion, interest in natural products has increased quite significantly in the past decade. Medicinal plants as well as their secondary metabolites have been assessed for possible bioactive agents for prevention of different human
Fig. 4 Chemical structures of AA (a) and UA (b)

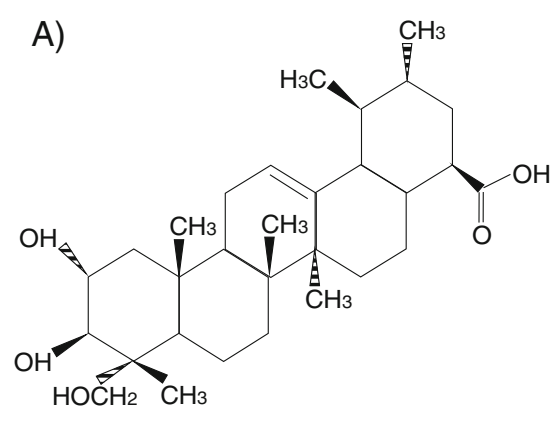

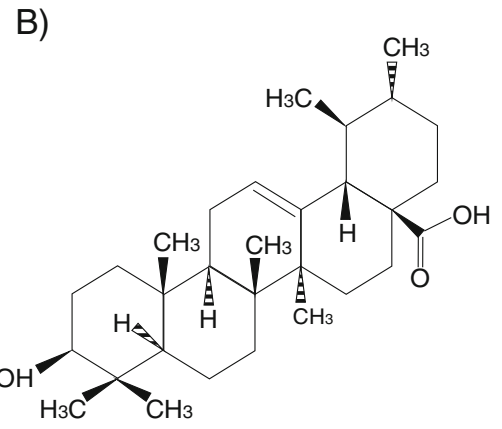


infections. Despite this, there are still many unknowns in this field, requiring further in-depth research.

Acknowledgments The authors thank Dr. Ewa Lewczyk the head of the Bacteriological Laboratory of the Academic Clinical Centre of the Wrocław Medical University for the isolation and species biochemical identification of bacterial strains. The authors are also grateful to Prof. Andrzej Hendrich for reading the manuscript and helpful discussions. This research was carried out under the project for a post-doc scientists of the Wroclaw Medical University, Wroclaw, Poland (protocol number: 5-S/PD-SN/2011).

Conflicts of interest The authors declare that they have no conflict of interest.

Open Access This article is distributed under the terms of the Creative Commons Attribution License which permits any use, distribution, and reproduction in any medium, provided the original author (s) and the source are credited.

\section{References}

Anuuk H, Hirmo S, Turi E, Mikelsaar M, Arak E, Wadstrom T (1999) Effect on cell surface hydrophobicity and susceptibility of Helicobacter pylori strains to medicinal plant extracts. FEMS Microbiol Lett 172:41-45

Barnabas CG, Nagarajan S (1988) Antimicrobial activity of flavonoids of some medicinal plants. Fitoterapia 3:508-510

Cho CW, Choi DS, Cardone MH, Kim CW, Sinskey AJ, Rha C (2006) Glioblastoma cell death induced by asiatic acid. Cell Biol Toxicol 22:393-408

Chung PY, Navaratnam P, Chung LY (2011) Synergistic antimicrobial activity between pentacyclic triterpenoids and antibiotics against Staphylococcus aureus strains. Ann Clin Microbiol Antimicrob 10:25-30

Clermont O, Bonacorsi S, Bingen E (2000) Rapid and simple determination of the Escherichia coli phylogenetic group. Appl Environ Microbiol 66:4555-4558

Clinical and Laboratory Standards Institute (2008) M100-S18. Performance standards for antimicrobial susceptibility testing. Seventeenth Informational Supplement Clinical Laboratory Standards Institute, Wayne

Cunningham DG, Vannozzi SA, Turk R, Roderick R, O'Shea E, Brilliant K (2004) Cranberry phytochemicals and their health benefits. In: Shahidi F, Weerasinghe DK (eds) Nutraceutical beverages: Chemistry, nutrition, and health effects. American Chemical Society, Washington, pp 35-51

Dykes GA, Amarowicz R, Pegg RB (2003) An antioxidant bearberry (Arctostaphylos uva-ursi) extractmodulates surface hydrophobicity of a wide range of food-related bacteria: implications for functional food safety. Food Control 14:515-518

Evans DJ, Evans DG, Young LS, Pitt J (1980) Hemagglutination typing of Escherichia coli: definition of seven hemagglutination types. J Clin Microbiol 12:235-242

Filocamo A, Bisignano C, D'Arrigo M, Ginestra G, Mandalari G, Galati EM (2011) Norfloxacin and ursolic acid: in vitro association and postantibiotic effect against Staphylococcus aureus. Lett Appl Microbiol 53:193-197

Fontanay S, Grare M, Mayer J, Finance C, Duval RE (2008) Ursolic, oleanolic and betulinic acids: antibacterial spectra and selectivity indexes. J Ethnopharmacol 120:272-276
Foo LY, Lu Y, Howell AB, Vorsa N (2000) A-type proanthocyanidin trimers from cranberry that inhibit adherence of uropathogenic P-fimbriated Escherichia coli. J Nat Prod 63:12251228

Hammar M, Arnqvist A, Bian Z, Olsen A, Normark S (1995) Expression of two csg operons is required for production of fibronectinand congo red-binding curli polymers in Escherichia coli K-12. Mol Microbiol 18:661-670

Ikeda Y, Murakami A, Ohigashi H (2008) Ursolic acid: an anti- and pro-inflammatory triterpenoid. Mol Nutr Food Res 52:26-42

Jahanshahi M, Azad S, Aslanbeigi B, Rahbar M (2010) Effect of subinhibitory concentrations of antibiotics and antibodies on the adherence of Escherichia coli to human uroepithelial cells in vitro. Res J Biol Sci 5:326-329

Johnson-White B, Buquo L, Zeinali M, Ligler FS (2006) Prevention of nonspecific bacterial cell adhesion in immunoassays by use of cranberry juice. Anal Chem 78:853-857

Justice SS, Hunstad DA, Seed PC, Hultgren SJ (2006) Filamentation by Escherichia coli subverts innate defenses during urinary tract infection. PNAS 103:19884-19889

Kurek A, Grudniak AM, Szwed M, Klicka A, Samluk Ł, Wolska KI, Janiszowska W, Popowska M (2010) Oleanolic acid and ursolic acid affect peptidoglycan metabolism in Listeria monocytogenes. Antonie van Leeuwenhoek 97:61-68

Lindahl M, Faris A, Wadstrom T, Hjerten S (1981) A new test based on "salting out" to measure relative surface hydrophobicity of bacterial cells. Biochim Biophys Acta 77:471-476

Melican K, Sandoval RM, Kader A, Josefsson L, Tanner GA, Molitoris BA, Richter-Dahlfors A (2011) Uropathogenic Escherichia coli P and Type 1 fimbriae act in synergy in a living host to facilitate renal colonization leading to nephron obstruction. PLoS Pathog 7: e1001298

Moodley R, Chenia H, Jonnalagadda SB, Koorbanally N (2011) Antibacterial and anti-adhesion activity of the pentacyclic triterpenoids isolated from the leaves and edible fruits of Carissa macrocarpa. J Med Plants Res 5:4851-4858

Mulvey MA (2002) Adhesion and entry of uropathogenic Escherichia coli. Cell Microbiol 4:257-271

Najar AG, Nejad MM, Mansouri S (2007) The comparison between virulence factors of Escherichia coli isolated from urinary tract infections and faecal flora. Res Pharm Sci 2:99-103

Nishino C, Enoki N, Tawata S, Mori A, Kobayashi K, Fukushima M (1987) Antibacterial activity of flavonoids against Staphylococcus epidermidis, a skin bacterium. Agric Biol Chem 51:139-143

Nostro A, Cannatelli MA, Crisafi G, Musolino AD, Procopio F, Alonzo V (2004) Modifications of hydrophobicity, in vitro adherence and cellular aggregation of Streptococcus mutans by Helichrysum italicum extract. Lett Appl Microbiol 38:423-427

Pizarro-Cerda J, Cossart P (2006) Bacterial adhesion and entry into host cells. Cell 124:715-727

Prades J, Vogler O, Alemany R, Gomez-Florit M, Funari SS, RuizGutierrez V, Barcelo F (2011) Plant pentacyclic triterpenic acids as modulators of lipid membrane physical properties. Biochim Biophys Acta 1808:752-760

Rafat M, Fonga KW, Goldsipe A, Stephenson BC, Coradetti ST, Sambandan TG, Sinskey AJ, Rha C (2008) Association (micellization) and partitioning of aglycon triterpenoids. J Colloid Interface Sci 325:324-330

Rahim ZH, Khan HB (2006) Comparative studies on the effect of crude aqueous (CA) and solvent (CM) extracts of clove on the cariogenic properties of Streptococcus mutans. J Oral Sci 48:117-123

Raksha R, Srinivasa H, Macaden RS (2003) Occurrence and characterization of uropathogenic Escherichia coli in urinary tract infections. Indian J Med Microbiol 21:102-107

Rauha JP, Remes S, Heinonen M, Hopia A, Kähkönen M, Kujala T, Pihlaja K, Vuorela H, Vuorela P (2000) Antimicrobial effects of 
Finnish plant extracts containing flavonoids and other phenolic compounds. Int J Food Microbiol 56:3-12

Razak FA, Rahim ZH (2003) The anti-adherence effect of Piper betle and Psidium guajava extracts on the adhesion of early settlers in dental plaque to saliva-coated glass surfaces. J Oral Sci 45:201206

Saralaya V, Bhat G, Kamath A, Shivananda PG (2004) Effect of trace elements on surface hydrophobicity and adherence of Escherichia coli to uroepithelial cells. Indian J Exp Biol 42:681-685

Sunman E, Gopalkrishna Bhat K, Hegde BM (2001) Bacterial adherence and immune response in recurrent UTI. Int J Gynaecol Obstet 75:263-268

Szakiel A, Ruszkowski D, Grudniak A, Kurek A, Wolska KI, Doligalska M, Janiszowska W (2008) Antibacterial and antiparasitic activity of oleanolic acid and its glycosides isolated from marigold (Calendula officinalis). Planta Med 74:1709-1715

Turi E, Turi M, Anuuk H, Arak E (1999) Action of aqueous extracts of bearberry and cowberry leaves and wild camomile and pineappleweed flowers on Escherichia coli surface structures. Pharm Biol $37: 127-133$
Wen X, Sun H, Liu J, Wu G, Zhang L, Wu X, Ni P (2005) Pentacyclic triterpenes. Part 1: The first examples of naturally occurring pentacyclic triterpenes as a new class of inhibitors of glycogen phosphorylases. Bioorg Med Chem Lett 15:4944-4948

Wojnicz D, Jankowski S (2007) Effects of subinhibitory concentrations of amikacin and ciprofloxacin on the hydrophobicity and adherence to epithelial cells of uropathogenic Escherichia coli strains. Int J Antimicrob Agents 29:700-704

Wojnicz D, Sycz Z, Walkowski S, Gabrielska J, Aleksandra W, Alicja K, Anna SL, Hendrich AB (2012) Study on the influence of cranberry extract Żuravit SOS $\left({ }^{\circledR}\right)$ on the properties of uropathogenic Escherichia coli strains, their ability to form biofilm and its antioxidant properties. Phytomedicine 19:506-514

Yamanaka A, Kimizuka R, Kato T, Okuda K (2004) Inhibitory effects of cranberry juice on attachment of oral streptococci and biofilm formation. Oral Microbiol Immunol 9:150-154

Yatsuda R, Rosalen PL, Cury JA, Murata RM, Rehder VL, Melo LV, Koo H (2005) Effects of Mikania genus plants on growth and cell adherence of mutans streptococci. J Ethnopharmacol 97:183-189 